\title{
Substitution effects of rice for corn grain in total mixed ration on rumen fermentation characteristics and microbial community in vitro
}

\author{
Daekyum Yoo "\# , Muhammad Mahboob Ali Hamid ${ }^{1 \#}$, Hanbeen Kim", \\ Joonbeom Moon ${ }^{1}$, Jaeyong Song ${ }^{2}$, Seyoung Lee ${ }^{3}$ and Jakyeom Seo ${ }^{1 *}$ \\ ${ }^{1}$ Department of Animal Science, Life and Industry Convergence Research Institute, Pusan National \\ University, Miryang 50463, Korea \\ 2Institute of Livestock, Nonghyup Co. Ltd., Ansung 17558, Korea \\ ${ }^{3}$ Division of Animal Husbandry, Yonam College, Cheonan 31005, Korea
}

Received: Jun 10, 2020

Revised: Jun 18, 2020

Accepted: Jun 19, 2020

\#These authors contributed equally to this work.

*Corresponding author Jakyeom Seo

Department of Animal Science, Life and Industry Convergence Research Institute, Pusan National University, Miryang 50463, Korea.

Tel: +82-55-350-5513

E-mail: jseo81@pusan.ac.kr

Copyright (c) 2020 Korean Society of Animal Sciences and Technology. This is an Open Access article distributed under the terms of the Creative Commons Attribution Non-Commercial License (http:// creativecommons.org/licenses/by$\mathrm{nc} / 4.0 /$ ) which permits unrestricted non-commercial use, distribution, and reproduction in any medium, provided the original work is properly cited.

ORCID

Daekyum Yoo

https://orcid.org/0000-0002-6430-9539

M. Mahboob Ali Hamid

https://orcid.org/0000-0002-1109-5469

Hanbeen Kim

https://orcid.org/0000-0003-2803-7318

Joonbeom Moon

https://orcid.org/0000-0002-7793-8756

Jaeyong Song

https://orcid.org/0000-0002-8613-5605

Seyoung Lee

https://orcid.org/0000-0001-7991-0565

\begin{abstract}
This study determined the substitution effects of rice for corn as the main grain source in a total mixed ration (TMR). In vitro rumen fermentation characteristics and microbes were assessed using two experimental diets. Diets included 33\% dry matter (DM) of either corn (Corn TMR) or rice grains (Rice TMR). In a 48-h in vitro incubation, DM digestibility (IVDMD), neutral detergent fiber degradability (IVNDFD), crude protein digestibility (IVCPD), volatile fatty acids (VFAs), pH and ammonia nitrogen $\left(\mathrm{NH}_{3}-\mathrm{N}\right)$ were estimated. Gas production has been calculated at 3, 6, 12, 24 and $48 \mathrm{~h}$. Our results indicate that the gas production, VFAs, IVDMD, and IVNDFD of Rice TMR were higher than those of Corn TMR $(p<0.05)$. Ruminal $\mathrm{pH}$ and total fungi were significantly higher in Corn TMR $(p<0.05)$ than in Rice TMR; however, $\mathrm{NH}_{3}-\mathrm{N}$ and IVCPD were not affected by treatment type. In conclusion, substituting rice for corn at 33\% DM in TMR appears to have no negative effects on in vitro rumen fermentation characteristics. Therefore, rice grains are an appropriate alternative energy source in early fattening stage diets of beef cattle.
\end{abstract}

Keywords: Rice grains, Corn grains, Total mixed ration, In vitro fermentation

\section{INTRODUCTION}

The increasing import of agricultural feed, along with grain price volatility, origin, and nutritional value, is raising concerns about the ability of alternative energy sources to meet the increasing demands of Hanwoo beef production in Korea. Corn is an important feed source for domesticated animals, including farm animals, and an essential commodity for processing industrial bioethanol [1]. Approximately $99 \%$ of the corn used as feedstock in Korea is imported from the U.S. corn belt owing to its low cost and the region's production efficiency [2]. However, because of the rice cultivation reduction program initiated by the Korean government in 2015 to stabilize rice grain stockholding, rice is becoming more commonly used as a livestock feed in this country [3]. Korea is expected to use 450,000 MT of rice for 
Jakyeom Seo

https://orcid.org/0000-0002-9176-5206

Competing interests

No potential conflict of interest relevant to

this article was reported.

Funding sources

This work was supported by the Rural

Development Administration, Republic of

Korea (Project No. PJ01285001).

Acknowledgements

Not applicable.

Availability of data and material

Upon reasonable request, the datasets

of this study can be available from the

corresponding author.

Authors' contributions

Conceptualization: Yoo D, Kim H, Song J, Lee S.

Data curation: Yoo D, Kim H, Moon J.

Formal analysis: Yoo D, Moon J, Seo J.

Methodology: Hamid MMA, Kim H, Lee S,

Seo J.

Software: Yoo D, Kim H, Moon J.

Validation: Hamid MMA, Song J, Seo J.

Investigation: Yoo D, Kim H, Moon J.

Writing - original draft: Yoo D, Hamid MMA, Kim H, Seo J.

Writing - review \& editing: Yoo D, Hamid MMA, Kim H, Seo J.

Ethics approval and consent to participate The protocols for this study regarding animal use were reviewed and accepted by the Animal Research Ethics Committee of Pusan National University (Pusan, Korea, PNU-2019-2239). feed in the 2019/2020 marketing year, with most of the combined rice stocks from previous years being reduced by the end of 2020 [4].

The characteristics of ruminal starch degradation vary depending on the type of cereal grain involved. Rice starch is digested more rapidly and has a higher effective degradability in the rumen than corn starch $[5,6]$. There are few studies evaluating the use of corn and rice in beef production. Despite the similar chemical composition and nutritive value of these grains, they exhibit different degradation characteristics in in vitro rumen fermentation systems with total mixed rations (TMRs) [7]. For example, in growing Hanwoo steer diets, as a 20\% dry matter (DM) replacement of rice presented higher in vitro dry matter digestibility (IVDMD), in vitro crude protein digestibility (IVCPD), and volatile fatty acid (VFA) production than corn [8].

In dairy cow diets, $31 \% \mathrm{DM}$ of rice substituted corn had a low impact on dry matter intake (DMI), milk yield and milk composition [9]. Nevertheless, in Korean early fattening stage steering diets for higher beef marbling, there are no findings regarding the use of rice as a corn replacement up to 33\% DM. Rice as an alternative to corn for energy-rich diets can be essential for integrated crop and livestock production systems [10], balancing and boosting Hanwoo cattle productivity. Including energy-rich grains in fattening TMR diets can affect productivity and rumen fermentation characteristics [2]. Therefore, this study investigates the effects of substituting corn with rice as the main energy source at 33\% DM in early fattening stage TMR diets on rumen fermentation characteristics and microbial populations.

\section{MATERIALS AND METHODS}

The protocols regarding the use of animal were closely examined and accepted by the Animal Research Ethics Committee of Pusan National University (Pusan, Korea, PNU-2019-2239).

\section{Preparation of experimental diet and chemical analysis}

The main ingredients of experimental TMR used in this study were timothy hay, alfalfa, rice, corn, and concentrate mixture (Nonghyup Feed Company, Miryang, Korea), and the dietary formulas along with chemical constituents of experimental TMR are described in Table 1. The experimental treatment consisted of two types of TMR: 1) The TMR containing 33\% flaked corn (Corn TMR), 2) The TMR containing 33\% rice grain (Rice TMR).

All the feed ingredients were air dried at $60^{\circ} \mathrm{C}$ for $72 \mathrm{~h}$ and then milled using cyclone mill equipped with a $1 \mathrm{~mm}$ screen (Foss Tecator Cyclotec 1093, Foss, Hillerød, Denmark). The DM (\#934.01), crude protein (CP; \#976.05), acid detergent fiber (ADF; \#973.18), ether extract (EE; \#920.39), and ash (\#942.05) were analyzed by the official methods of AOAC International [11]. According to the Kjeldahl process, total amount of nitrogen was calculated by a nitrogen combustion analyzer (Leco FP-528, Leco, St. Joseph, MI, USA) and multiplied by 6.25 to determine CP content. To determine the fiber content, lignin and neutral detergent fiber (aNDF) were evaluated according to the method described by Van Soest et al. [12]. The heat-stable form of $\alpha$-amylase was utilized for estimation of aNDF and the volume of aNDF included residual ash. The chemical analysis for the Cornell Net Carbohydrate and Protein system (CNCPS) fraction analyzed with several modifications at Cumberland Valley Analytical Service (MD, USA) [13] and described in Table 2. Soluble protein (SOLP) was analyzed, and for each residue, the content of neutral detergent insoluble crude protein (NDICP) and acid detergent insoluble crude protein (ADICP) was also evaluated. The starch and ethanol-soluble carbohydrate (ESC) were measured. For carbohydrate fraction, A fraction (CA) was estimated to be same with ESC, and B1 fraction (CB1) represented starch. B2 fraction (CB2) was estimated as Non-fiber carbohydrate (NFC) - CA - CB1, and B3 fraction 
Table 1. Chemical composition and dietary formulation of the experimental feeds

\begin{tabular}{|c|c|c|}
\hline \multirow{2}{*}{ Items } & \multicolumn{2}{|c|}{ Treatments $^{1)}$} \\
\hline & Corn TMR & Rice TMR \\
\hline \multicolumn{3}{|l|}{ Ingredients (\% DM) } \\
\hline Corn flake & 33.0 & 0 \\
\hline Rice grain & 0 & 33.0 \\
\hline Commercial concentrate mix & 36.0 & 36.0 \\
\hline Alfalfa & 7.0 & 7.0 \\
\hline Timothy & 23.5 & 23.5 \\
\hline Vitamin and mineral $\mathrm{mix}^{2}$ & 0.5 & 0.5 \\
\hline \multicolumn{3}{|c|}{ Chemical composition (DM or as stated) } \\
\hline $\mathrm{DM}(\%$ as fed $)$ & 65.0 & 65.0 \\
\hline $\mathrm{CP}$ & 14.9 & 14.8 \\
\hline aNDF & 30.6 & 29.5 \\
\hline ADF & 19.5 & 18.5 \\
\hline Lignin & 4.45 & 4.17 \\
\hline Sugar & 5.98 & 5.23 \\
\hline Starch & 35.73 & 38.02 \\
\hline $\mathrm{EE}$ & 3.50 & 3.19 \\
\hline Ash & 5.22 & 5.42 \\
\hline TDN & 72.4 & 73.8 \\
\hline $\mathrm{NE}_{\mathrm{m}}(\mathrm{Mcal} / \mathrm{kg}$ of DM) & 1.67 & 1.71 \\
\hline \multicolumn{3}{|c|}{ 1)Corn TMR, control diet containing 33\% flaked corn; Rice TMR, the diet containing 33\% rice grain. } \\
\hline \multicolumn{3}{|c|}{$\begin{array}{l}{ }^{2} \text { Vitamin A, 33,330,000 IU/kg; vitamin D, 40,000,000 IU/kg; vitamin E, } 20.86 \text { IU/kg; Cu, } 20 \text { mg/kg; Mn, } 90 \text { mg/kg; Zn, } 100 \text { mg/kg; } \\
\text { Fe, } 250 \text { mg/kg; I, } 0.4 \text { mg/kg; Se, } 0.4 \text { mg/kg. }\end{array}$} \\
\hline
\end{tabular}

$A D F$, acid detergent fiber; $E E$, ether extract; TDN, total digestible nutrients; $\mathrm{NE}_{m}$, net energy for maintenance.

(CB3) was calculated with the following equation (aNDF - NDICP) $-(2.4 \times$ Acid detergent lig$\operatorname{nin}[\mathrm{ADL}])$. $\mathrm{C}$ fraction $(\mathrm{CC})$ was evaluated as $2.4 \times \mathrm{ADL}$. For protein fraction, $\mathrm{A}$ and $\mathrm{B} 1$ fractions $(\mathrm{PA}+\mathrm{PB} 1)$ was equal to SOLP, and B2 fraction was estimated according to the equation $100-$ NDICP - SOLP, and B3 fraction was calculated by the equation NDICP - ADICP. C fraction of protein $(\mathrm{PC})$ was equal to $\mathrm{ADICP}$. To estimate the total digestible nutrient (TDN) and net energy for maintenance $\left(\mathrm{NE}_{\mathrm{m}}\right)$, several equations in the $\mathrm{NRC}$ were used $[14,15]$. NFC was calculated as follows [15]:

$$
100-\text { ash }-\mathrm{EE}-\mathrm{CP}-(\mathrm{aNDF}-\mathrm{NDICP})
$$

\section{In vitro fermentation}

Rumen fluid has been used for the in vitro incubation and collected from two cannulated Holstein cattle (body weight [BW] $650 \pm 30 \mathrm{~kg}$ ), before they were fed morning feed at the Center for Agriculture Research of Pusan National University (Miryang, Korea). The cannulated cattle were completely adapted to a diet comprising $400 \mathrm{~g} / \mathrm{kg}$ of a commercial concentrate mix and about 600 $\mathrm{g} / \mathrm{kg}$ of timothy hay. Collection of rumen fluid was done in a thermos bottle and then immediately transferred to the laboratory within 30 minutes. Eight layers of cheesecloth were used to filter rumen fluid and then thoroughly mixed with three times volume of in vitro buffer solution under strict anaerobic condition [16]. Each ground experimental substrate $(0.5 \mathrm{~g})$ was placed into the nylon bags (R510, Ankom Technology, NY, USA) and were subsequently sealed and transferred into 
Table 2. Carbohydrate $(\% \mathrm{CHO})$ and protein $(\% \mathrm{CP})$ fractions of the experimental feeds (\%DM)

\begin{tabular}{lcc}
\hline \multirow{2}{*}{ Items } & \multicolumn{2}{c}{ Treatments $^{1)}$} \\
\cline { 2 - 3 } & Corn TMR & Rice TMR \\
\hline Carbohydrate fraction $(\% \mathrm{CHO})^{2)}$ & 7.83 & 6.83 \\
CA & 46.78 & 49.67 \\
CB1 & 8.24 & 7.94 \\
CB2 & 23.04 & 22.48 \\
CB3 & 13.99 & 13.07 \\
CC & & \\
Protein fraction $(\% \mathrm{CP})^{3)}$ & 23.84 & 23.67 \\
PA + PB1 & 61.24 & 61.54 \\
PB2 & 5.86 & 5.92 \\
PB3 & 10.70 & 10.38 \\
PC & &
\end{tabular}

${ }^{1)}$ Corn TMR, control diet containing 33\% flaked corn; Rice TMR, the diet containing 33\% rice grain.

${ }^{2)} \mathrm{CA}$, carbohydrate A fraction; CB1, carbohydrate B1 fraction; $\mathrm{CB} 2$, carbohydrate B2 fraction; CB3, carbohydrate B3 fraction; $\mathrm{CC}$, carbohydrate $\mathrm{C}$ fraction.

${ }^{3)} \mathrm{PA}+\mathrm{PB} 1$, protein $\mathrm{A}$ and $\mathrm{B} 1$ fraction; PB2, protein B2 fraction; PB3, protein B3 fraction; PC, protein C fraction.

TMR, total mixed ration; $\mathrm{DM}$, dry matter; $\mathrm{CHO}$, carbohydrate; $\mathrm{CP}$, crude protein.

$250 \mathrm{~mL}$ serum bottles. Each treatment had four replicates and four bags were used for each bottle. In each bottle, $140 \mathrm{~mL}$ of mixture containing rumen fluid and in vitro buffer solution were put with continuous flushing of $\mathrm{O}_{2}$-free $\mathrm{CO}_{2}$ gas. The bottles were capped with butyl rubber caps and incubated at $20 \mathrm{rpm}$ for $48 \mathrm{~h}$ and $39^{\circ} \mathrm{C}$ on a rotary incubator (JSSI-300 T, JS Research, Gongju, Korea).

After 48-h incubation, the content of IVDMD, in vitro aNDF degradability (IVNDFD), IVCPD, $\mathrm{pH}, \mathrm{VFA}$, and ammonia nitrogen $\left(\mathrm{NH}_{3}-\mathrm{N}\right)$ were analyzed. The gas production at 3, 6, 12, 24, and $48 \mathrm{~h}$ was estimated by a pressure transducer (Sun Bee Instrument, Seoul, Korea) [17]. The gas parameters were measured using a simple exponential model following equation [18]:

$$
\begin{array}{ll}
V_{T}=0 & (0 \leq \mathrm{T} \leq \mathrm{L}) \\
V_{T}=V_{\max } \times\left\{1-\mathrm{e}^{[-\operatorname{lkg} \times(T-L)]}\right\} & (\mathrm{T} \geq \mathrm{L})
\end{array}
$$

The $T$ is time (h), $L$ is lag time (h), and $e$ is the exponential function. The value of $K_{g}$ is the fractional rate of gas production $\left(\mathrm{h}^{-1}\right)$. The $V_{\max }$ is the theoretical maximum production of gas $(\mathrm{mL})$, and $V_{T}$ is volume of gas at time $T(\mathrm{~mL})$. After 48-h of incubation, the bottle caps were removed transferred into ice to stop microbial fermentation. Subsequently, bags were removed from the incubated bottles and rinsed with tap water until it was clear. All the sealed bags were weighed for the estimation of IVDMD after oven drying at $60^{\circ} \mathrm{C}$ for $72 \mathrm{~h}$. For the assessment of IVNDFD, the neutral detergent fiber (NDF) content of each weighted bag was assessed [19]. Centrifugation of the sample fluid $(1.8 \mathrm{~mL})$ at $20.000 \times \mathrm{g}$, at $4^{\circ} \mathrm{C}$ for 20 minutes, and then removal of the supernatant. The remaining pellet was stored at $-80^{\circ} \mathrm{C}$ until extracting microbial DNA. The rumen fluid $\mathrm{pH}$ was measured using the $\mathrm{pH}$ meter (FP20, Mettler Toledo, OH, USA) and the remaining rumen fluid was centrifuged at $15.000 \times \mathrm{g}$, at $4^{\circ} \mathrm{C}$, for $10 \mathrm{~min}$, and stored at $-20^{\circ} \mathrm{C}$ for analysis of VFA and $\mathrm{NH}_{3}-\mathrm{N}$. Before carrying out the VFA and $\mathrm{NH}_{3}-\mathrm{N}$ analysis, the stored rumen fluid was melted and centrifuged for $15 \mathrm{~min}$ at $20,000 \times \mathrm{g}$. The supernatant $(200 \mu \mathrm{L})$ was diluted with $800 \mu \mathrm{L}$ of ethyl alcohol (4023-2304, Daejung Chemicals, Siheung, Korea) and the diluted mixture were analyzed on VFA using a gas chromatography (Agilent 7890A, Agilent Technology, CA, USA) mounted with a flame ionization detector and Nukol ${ }^{\mathrm{TM}}$ Fused silica capillary column $(30 \mathrm{~m} \times 250 \mu \mathrm{m} \times$ 
$0.25 \mu \mathrm{m}$; Supelco, PA, USA). The temperature (oven, injector, detector) was set at 90, 90-200, and $230^{\circ} \mathrm{C}$, respectively, and the nitrogen was used as a carrier gas (flow rate, $30 \mathrm{~mL} / \mathrm{min}$ ). The $\mathrm{NH}_{3}-\mathrm{N}$ concentration was measured by the described method of Chaney and Marbach [20], with some adjustments. Briefly, the supernatant of centrifuged rumen fluid $(2 \mu \mathrm{L})$ was mixed with phenol color reagent $(100 \mu \mathrm{L}, 0.25 \mathrm{~g}$ of sodium nitroferricyanide, $50 \mathrm{~g}$ of phenol, $1 \mathrm{~L}$ distilled water) and alkali hypochlorite $(100 \mu \mathrm{L}, 16.8 \mathrm{~mL}$ of sodium hypochlorite, $25 \mathrm{~g}$ of sodium hydroxide, $1 \mathrm{~L}$ distilled water). The mixture was then incubated at $37^{\circ} \mathrm{C}$ for 15 minutes and the concentration of $\mathrm{NH}_{3}-\mathrm{N}$ was analyzed by the absorbance at an optical density $(630 \mathrm{~nm}$ ) using a microplate reader (iMARK, BioRad, CA, USA).

\section{Microbial genomic DNA extraction and quantitative polymerase chain reaction}

The genomic DNA from pellet was extracted by the method described by Yu and Mosrrison [21]. The DNA concentration and purity were evaluated with a NanoDrop (ND-1000, Thermo Fisher, MA, USA). Quantitative polymerase chain reaction (qPCR) was carried out using a CFX 96 Touch system (Bio-Rad Laboratories Inc., CA, USA). The primer set used in this study are represented in Table 3 [22,23]. Each reaction mixture volume was $20 \mu \mathrm{L}$ containing $10 \times$ buffer $(2 \mu \mathrm{L}$, BioFACT, Daejeon, Korea), $10 \mathrm{mM}$ dNTP mixture $(0.5 \mu \mathrm{L}$, BioFACT, Daejeon, Korea), 10-fold diluted genomic DNA $(1 \mu \mathrm{L}), 10 \mu \mathrm{M}$ primer-set (each $1 \mu \mathrm{L}), 1 \mu \mathrm{L}$ reverse $(10 \mu \mathrm{M})$, taq polymerase $(0.1 \mu \mathrm{L}$, BioFACT, Daejeon, Korea), Evagreen (1 $\mu \mathrm{L}$, SolGent, Daejeon, Korea), and bio-grade water (13.4 $\mu \mathrm{L})$. All the reactions were conducted in triplicate, the procedure condition of $\mathrm{qPCR}$ was as follows: initial denaturation of DNA at $95^{\circ} \mathrm{C}$ for $10 \mathrm{~min}$, and 40 cycles of denaturation at $95^{\circ} \mathrm{C}$ for 30 s, annealing at $60^{\circ} \mathrm{C}$ for $30 \mathrm{~s}$, and elongation at $72^{\circ} \mathrm{C}$ for $30 \mathrm{~s}$, followed by a final elongation at $72^{\circ} \mathrm{C}$ for $5 \mathrm{~min}$. At the end of extension stage, fluorescence was noted. All the amplicon specificity was checked through dissociation curve by rising the temperature, at a rate of $1^{\circ} \mathrm{C}$ per $30 \mathrm{~s}$, from $60^{\circ} \mathrm{C}$ to $95^{\circ} \mathrm{C}$. A standard plasmid having respective target sequence was used for absolute quantification of each microbe. The copy number of each standard primer was calculated as described by [24] and diluted with 10-fold serial dilution. CFX manager software (Bio-Rad, CA, USA) was used to compare the quantification of each microbe with the standard curve.

\section{Statistical analysis}

Statistical analysis was done by the PROC TTEST procedure of SAS 9.3 (SAS Institute, NC, USA), and the statistical significance was defined at $p<0.05$. The statistical trend was represented at $0.05 \leq p<0.1$.

Table 3. Primers used for quantitative PCR

\begin{tabular}{lclccc}
\hline Target species & Primer & \multicolumn{1}{c}{ Sequence $\left(\mathbf{5}^{\prime} \rightarrow \mathbf{3}^{\prime}\right)$} & $\begin{array}{l}\text { Size } \\
(\mathbf{b p})\end{array}$ & Efficiency $^{\mathbf{1})}$ & References \\
\hline General bacteria & F & CGGCAACGAGCGCAACCC & 130 & 1.89 & {$[11]$} \\
& R & CCATTGTAGCACGTGTGTAGCC & & & \\
Protozoa & F & GCTTTCGWTGGTAGTGTATT & 223 & 1.92 & {$[14]$} \\
& R & CTTGCCCTCYAATCGTWCT & & & \\
Fungi & F & GAGGAAGTAAAAGTCGTAACAAGGTTTC & 120 & 2.06 & {$[11]$} \\
& R & CAAATTCACAAAGGGTAGGATGATT & & & \\
\hline
\end{tabular}

${ }^{1)}$ Efficiency is calculated as $\left[10^{-1 / \text { slope }}\right]$.

$\mathrm{PCR}$, polymerase chain reaction; bp, base pair. 


\section{RESULTS}

The Rice TMR effects on gas production and parameters in comparison with those of Corn TMR are presented in Table 4. In vitro gas production was significantly higher in Rice TMR than in Corn TMR at all observed time points $(p<0.05)$. In the fitted gas parameters, $V_{\max }$ was also significantly higher in Rice TMR $(p<0.01)$ than in Corn TMR, whereas no significant difference in $K_{g}$ was detected. Ruminal $\mathrm{pH}$ was higher in the Corn TMR diet $(p<0.05)$ than in the Rice TMR diet; however, no difference in the $\mathrm{NH}_{3}-\mathrm{N}$ concentration was detected between the two TMR diets $(p=0.44)$. Total VFA production was significantly higher in Rice TMR $(p<0.01)$ than in Corn TMR; however, regarding individual VFAs, there were no significant differences in the acetate, propionate, and butyrate concentrations $(p=0.17, p=0.63$, and $p=0.39$, respectively). The ratio of acetate to propionate was therefore no different $(p=0.45)$. Regarding ruminal digestibility indices, IVDMD and IVNDFD were higher in Rice TMR than in Corn TMR $(p<0.01$ for both), whereas no difference was detected for IVCPD ( $p=0.24$; Table 5$)$. In the ruminal microbial community,

Table 4. In vitro gas production characteristics of experimental diets incubated in buffered rumen fluid

\begin{tabular}{|c|c|c|c|c|c|}
\hline \multirow{2}{*}{ Items } & \multirow{2}{*}{$\mathbf{n}$} & \multicolumn{2}{|c|}{ Treatments $^{1)}$} & \multirow{2}{*}{ SEM } & \multirow{2}{*}{$p$-value } \\
\hline & & Corn TMR & Rice TMR & & \\
\hline \multicolumn{6}{|l|}{ Gas (mL/g DM) } \\
\hline $6 \mathrm{~h}$ & 4 & 47.6 & 51.2 & 1.48 & $<0.05$ \\
\hline $12 \mathrm{~h}$ & 4 & 103.6 & 113.3 & 2.18 & $<0.01$ \\
\hline \multicolumn{6}{|c|}{ Fitted parameters of gas ${ }^{2)}$} \\
\hline $\mathrm{V}_{\max }$ & 4 & 269.6 & 286.2 & 4.06 & $<0.01$ \\
\hline $\mathrm{K}_{\mathrm{g}}$ & 4 & 0.039 & 0.047 & 0.0011 & 0.21 \\
\hline
\end{tabular}

${ }^{1)}$ Corn TMR, control diet containing 33\% flaked corn; Rice TMR, the diet containing 33\% rice gain.

${ }^{2} \mathrm{~V}_{\text {max }}$, theoretical maximum gas production $(\mathrm{mL} / \mathrm{g} \mathrm{DM}) ; \mathrm{K}_{\mathrm{g}}$, fractional rate of gas production $\left(\mathrm{h}^{-1}\right)$.

TMR, total mixed ration; DM, dry matter; SEM, standard error of the mean.

Table 5. Fermentation characteristics of experimental diets incubated in buffered rumen fluid

\begin{tabular}{|c|c|c|c|c|c|}
\hline \multirow{2}{*}{ Items } & \multirow{2}{*}{$\mathbf{n}$} & \multicolumn{2}{|c|}{ Treatments $^{1)}$} & \multirow{2}{*}{ SEM } & \multirow{2}{*}{$p$-value } \\
\hline & & Corn TMR & Rice TMR & & \\
\hline $\mathrm{pH}$ & 4 & 6.2 & 6.1 & 0.02 & $<0.05$ \\
\hline $\mathrm{NH}_{3}-\mathrm{N}(\mathrm{mg} / 100 \mathrm{~mL})$ & 4 & 35.3 & 33.2 & 2.47 & 0.44 \\
\hline Total VFA (mM) & 4 & 84.6 & 91.5 & 1.71 & $<0.01$ \\
\hline Acetate (mmoL/moL) & 4 & 544.2 & 551.3 & 4.52 & 0.17 \\
\hline Propionate (mmoL/moL) & 4 & 276.3 & 274.3 & 3.99 & 0.63 \\
\hline Butyrate (mmoL/moL) & 4 & 131.5 & 129.7 & 1.90 & 0.39 \\
\hline$A: P$ ratio & 4 & 1.98 & 2.01 & 0.044 & 0.45 \\
\hline IVDMD (\%) & 4 & 82.9 & 87.0 & 1.01 & $<0.01$ \\
\hline IVNDFD ( $\%$ aNDF) & 4 & 64.7 & 70.0 & 1.14 & $<0.01$ \\
\hline IVCPD (\% CP) & 4 & 85.1 & 88.3 & 2.49 & 0.24 \\
\hline
\end{tabular}

${ }^{11}$ Corn TMR, control diet containing 33\% flaked corn; Rice TMR, the diet containing $33 \%$ rice gain.

TMR, total mixed ration; SEM, standard error of the mean; $\mathrm{NH}_{3}-\mathrm{N}$, ammonia nitrogen; VFA, volatile fatty acid; $\mathrm{A}: \mathrm{P}$ ratio, acetate to propionate ratio; IVDMD, in vitro dry matter degradability; IVNDFD, in vitro neutral detergent fiber degradability; aNDF, neutral detergent fiber analyzed with heat-stable $\alpha$-amylase; IVCPD, in vitro crude protein degradability; CP, crude protein. 
the substitution of rice for corn tended to increase the total protozoal count $(p=0.08)$ in Rice TMR, and significantly increase the total fungal count $(p<0.01)$ in Corn TMR. However, the total bacterial count was not affected by treatment type ( $p=0.57$; Table 6$)$.

\section{DISCUSSION}

High-energy grain sources are commonly used to enhance growth efficiency in early fattening diets for beef cattle. The availability of a grain source varies with grain type and processing methods. The use of high-energy grain sources with a faster digestion rate will induce ruminal acidosis in the transition period from a high forage to a high grain diet [25]. Thus, it is important to select dietary energy sources that are appropriate to meet nutritional requirements while maintaining a healthy rumen environment. Yang et al. [7] reported that the use of rice grain in TMR at 70\% DM can lead to higher IVDMD than the use of corn and wheat grain. Replacing corn with rice at 20\% DM leads to higher IVDMD and VFA production without significant change to ruminal $\mathrm{pH}$ [8], suggesting that there is potential to replace conventional grains in fattening TMR diets.

In the present study, it was observed that the replacement of rice for corn at 33\% DM in TMR increased not only gas emissions at all observed time points but also $V_{\max }$. The amount of gas emitted is calculated during in vitro ruminal fermentation to predict the DM degradability of cereal grains used as ruminant feed [26]. However, protein is another essential nutrient for energy-rich TMR ruminant diets, providing an efficient supply of amino acids that serve as building blocks for body tissues in growing beef cattle [27]. In this study, $\mathrm{NH}_{3}-\mathrm{N}$ concentration was not different between the treatments $(p=0.44)$. Furthermore, during the in vitro fermentation of Rice and Corn TMR, IVCPD was more than $80 \%$ at $48 \mathrm{~h}$ of incubation without any significant differences $(p=$ 0.24 ). These findings are close to those of previous studies in which the substitution of rice grain at $70 \%$ and $20 \% \mathrm{DM}$ resulted in higher IVCPD, whereas the concentration of $\mathrm{NH}_{3}-\mathrm{N}$ between rice and corn TMR diets was not different $[7,8]$.

Cereal grains are important food sources, supplying energy reserves to sustain the dietary needs of growing beef and dairy cattle [28]. Microbial fermentation results in VFAs as the final products of a ruminant's diet and provides $70 \%$ of the supplied energy; the conversion of propionate to glucose is beneficial to the body's growth and maintenance requirements [29]. In this study, Rice TMR had higher total concentrations of VFA, without any significant differences between the treatments regarding the individual VFA proportions and the acetate to propionate ratio. In a recent in vitro analysis, 20\% DM substitution of rice for corn in a TMR diet increased the total VFA while retaining a similar ratio of acetate to propionate [8]. Contrary to our findings, Oh et al. [30] reported decreased propionate and increased acetate in Hanwoo steer diets with 50\% DM of rice grains. However, compared to those with corn, lower acetate and higher propionate concentrations were

Table 6. Rumen microbial population of experimental diets incubated in buffered rumen fluid

\begin{tabular}{|c|c|c|c|c|c|}
\hline \multirow{2}{*}{ Items } & \multirow{2}{*}{$\mathbf{n}$} & \multicolumn{2}{|c|}{ Treatments $^{1)}$} & \multirow{2}{*}{ SEM } & \multirow{2}{*}{$p$-value } \\
\hline & & Corn TMR & Rice TMR & & \\
\hline \multicolumn{6}{|l|}{ Organism ${ }^{2)}$} \\
\hline Protozoa & 4 & 7.33 & 7.98 & 0.363 & 0.08 \\
\hline Fungi & 4 & 1.96 & 1.54 & 0.095 & $<0.01$ \\
\hline
\end{tabular}

${ }^{11}$ Corn TMR, control diet containing 33\% flaked corn; Rice TMR, the diet containing $33 \%$ rice gain.

${ }^{2)}$ General bacteria, $\times 10^{10}$ copies $/ \mathrm{mL}$ of rumen fluid; Protozoa, $\times 10^{9}$ copies $/ \mathrm{mL}$ of rumen fluid; Fungi, $\times 10^{7}$ copies $/ \mathrm{mL}$ of rumen fluid.

TMR, total mixed ration; SEM, standard error of the mean. 
identified with $40 \%$ DM of brown rice [5].

Heat-treated corn flakes are beneficial for ruminants, in that they provide a slow release of easily digested nutrients [31]. In addition, heat-treated cereal grains in the rumen may have improved digestibility owing to starch gelatinization [32]. However, our results show that an untreated rice grain TMR diet had higher IVDMD than a heat-treated corn flake TMR diet. Generally, NDF in the cereal grains is not particularly effective in stimulating rumination [33]. However, IVNDFD was significantly higher for Rice TMR during a 48-h in vitro incubation, despite the similarity of diet composition and nutrient values between the two TMR diets. In their comparison of steer diets, Oh et al. [30] recorded low fiber digestibility at 50 and 100\% DM substitution of rice for corn. Likewise, replacing corn with rice at 40\% DM at increasing levels in a lactating cattle diet decreased NDF digestibility [5].

Dietary carbon sources can be converted to energy via nutrient fermentation pathways of the rumen microbial biomass; bacteria, protozoa, and fungi are the three kingdoms that account for most microbial biomass [34]. Regarding the microbial community in the rumen, the substitution of rice grains tended to increase the protozoa $(p=0.08)$ and lead to a higher IVNDFD. However, total fungi were significantly higher for Corn TMR, and total bacteria did not differ between the treatments $(p=0.57)$. This may relate to the fact that fungi are anaerobic obligates that produce cellulases and xylanases. This allows them to more effectively derive nutrition from the fermentation of carbohydrates [35] in ruminants with diets containing comparatively high levels of cereal grains [33]. Substituting rice for corn at 33\% DM led to higher gas production, VFA, IVDMD, and IVNDFD. There was no significant difference between our two treatments regarding the number of ruminal bacteria present. However, the protozoal biomass tended to be greater in Rice TMR, whereas the fungi biomass was significantly greater in Corn TMR. The substitution of rice grains in the TMRs at a level of 33\% DM had no negative effects on rumen fermentation characteristics, and such diets can be used to grow Hanwoo steers. Further in vivo research studies will be helpful to evaluate the various growth performance parameters and physiological indicators for beef cattle during the finishing period in Korea.

\section{REFERENCES}

1. Qiao FQ, Wang F, Ren LP, Zhou ZM, Meng QX, Bao YH. Effect of steam-flaking on chemical compositions, starch gelatinization, in vitro fermentability, and energetic values of maize, wheat and rice. J Integr Agric. 2015;14:949-55. https://doi.org/10.1016/S20953119(14)60913-8

2. Hamid MMA, Park HY, Choi CW. Comparison of in vitro ruminal fermentation incubated with different levels of Korean corn grains with total mixed ration as a basal. Korean J Agric Sci. 2018;45:419-27.

3. Statistics Korea. Estimated rice production in 2019 [Internet]. 2019. [cited 2020 Apr 4]. http:// kostat.go.kr/portal/eng/pressReleases/1/index.board?bmode=read\&aSeq=378579

4. Choi S, Hinkle AF, Verdonk R. Republic of Korea grain and feed annual rice production stays steady despite government's rice reduction program. Wahington, DC: Foreign Agricultural Service, United States Department of Agriculture; 2019. Gain Report No.: KS1913

5. Miyaji M, Matsuyama H, Hosoda K. Effect of substituting brown rice for corn on lactation and digestion in dairy cows fed diets with a high proportion of grain. J Dairy Sci. 2014;97:95260. https://doi.org/10.3168/jds.2013-7046

6. Miyaji M, Matsuyama H, Hosoda K, Nonaka K. Effect of replacing corn with brown rice grain in a total mixed ration silage on milk production, ruminal fermentation and nitrogen 
balance in lactating dairy cows. Anim Sci J. 2012;83:585-93. https://doi.org/10.1111/j.17400929.2011.00996.x

7. Yang SJ, Kim HB, Moon JB, Kim NE, Park JK, Park BK, et al. Nutritional evaluation of total mixed rations containing rice grain in an in vitro rumen fermentation system. Korean J Agric Sci. 2018;45:741-78.

8. Yang S, Kim B, Kim H, Moon J, Yoo D, Baek YC, et al. Replacement of corn with rice grains did not alter growth performance and rumen fermentation in growing Hanwoo steers. Asian-Australas J Anim Sci. 2020;33:230-5. https://doi.org/10.5713/ajas.19.0691

9. Miyaji M, Matsuyama H, Hosoda K, Nonaka K. Milk production, nutrient digestibility and nitrogen balance in lactating cows fed total mixed ration silages containing steam-flaked brown rice as substitute for steam-flaked corn, and wet food by-products. Anim Sci J. 2013;84:483-8. https://doi.org/10.1111/asj.12026

10. Scheibler RB, Schafhäuser J, Rizzo FA, Nörnberg JL, Vargas DP, Silva JLS, et al. Replacement of corn grain by brown rice grain in dairy cow rations: Nutritional and productive effects. Anim Feed Sci Technol.2015;208:214-9. https://doi.org/10.1016/j.anifeedsci.2015.07.013

11. AOAC [Association of Official Analytical Chemists] International. Official methods of analysis of AOAC International. 18th ed. Gaithersburg, MD: AOAC Internationl; 2005.

12. Van Soest PJ, Robertson JB, Lewis BA. Methods for dietary fiber, neutral detergent fiber, and nonstarch polysaccharides in relation to animal nutrition.J Dairy Sci. 1991;74:3583-97. https:// doi.org/10.3168/jds.S0022-0302(91)78551-2

13. Fox DG, Tedeschi LO, Tylutki TP, Russell JB, Van Amburgh ME, Chase LE, et al. The cornell net carbohydrate and protein system model for evaluating herd nutrition and nutrient excretion. Anim Feed Sci Technol. 2004;112:29-78. https://doi.org/10.1016/j.anifeedsci.2003.10.006

14. National Research Council. Nutrient requirements of beef cattle: seventh revised edition: update 2000. Washington, DC: The National Academies Press; 2000.

15. National Research Council. Nutrient requirements of dairy cattle: seventh revised edition, 2001. Washington, DC: The National Academies Press; 2001.

16. Goering HK, Van Soest PJ. Forage fiber analyses: apparatus, reagents, procedures, and some applications. Washington, DC: Agricultural Research Service, United States Department of Agriculture; 1970.

17. Theodorou MK, Williams BA, Dhanoa MS, McAllan AB, France J. A simple gas production method using a pressure transducer to determine the fermentation kinetics of ruminant feeds. Anim Feed Sci Technol. 1994;48:185-97. https://doi.org/10.1016/0377-8401(94)90171-6

18. Schofield P, Pitt RE, Pell AN. Kinetics of fiber digestion from in vitro gas production. Anim Sci J. 1994;72:2980-91. https://doi.org/10.2527/1994.72112980x

19. Pell AN, Schofield P. Computerized monitoring of gas production to measure forage digestion in vitro. J Dairy Sci. 1993;76:1063-73. https://doi.org/10.3168/jds.S0022-0302(93)77435-4

20. Chaney AL, Marbach EP. Modified reagents for determination of urea and ammonia. Clin Chem. 1962;8:130-2. https://doi.org/10.1093/clinchem/8.2.130

21. Yu Z, Morrison M. Improved extraction of PCR-quality community DNA from digesta and fecal samples. Biotechniques. 2004;36:808-12. https://doi.org/10.2144/04365ST04

22. Denman SE, McSweeney CS. Development of a real-time PCR assay for monitoring anaerobic fungal and cellulolytic bacterial populations within the rumen. FEMS Microbiol Ecol. 2006;58:572-82. https://doi.org/10.1111/j.1574-6941.2006.00190.x

23. Khafipour E, Li S, Plaizier JC, Krause DO. Rumen microbiome composition determined using two nutritional models of subacute ruminal acidosis. J Appl Environ Microbiol. 2009;75:711524. https://doi.org/10.1128/AEM.00739-09 
24. Whelan JA, Russell NB, Whelan MA. A method for the absolute quantification of cDNA using real-time PCR. J Immunol Methods. 2003;278:261-9. https://doi.org/10.1016/S00221759(03)00223-0

25. Fernando SC, Purvis HT 2nd, Najar FZ, Sukharnikov LO, Krehbiel CR, Nagaraja TG, et al. Rumen microbial population dynamics during adaptation to a high-grain diet. Appl Environ Microbiol. 2010;76:7482-90. https://doi.org/10.1128/AEM.00388-10

26. Dijkstra J, Ellis JL, Kebreab E, Strathe AB, López S, France J, et al. Ruminal pH regulation and nutritional consequences of low pH. Anim Feed Sci Technol. 2012;172:22-33. https://doi. org/10.1016/j.anifeedsci.2011.12.005

27. Martın-Orúe SM, Balcells J, Vicente F, Castrillo C. Influence of dietary rumen-degradable protein supply on rumen characteristics and carbohydrate fermentation in beef cattle offered high-grain diets. Anim Feed Sci Technol. 2000;88:59-77. https://doi.org/10.1016/S03778401(00)00191-7

28. Lee SY, Kim WY, Ko JY, Ha JK. Effects of corn processing on in vitro and in situ digestion of corn grain in Holstein steers. Asian-Australas J Anim Sci. 2002;15:851-8. https://doi. org/10.5713/ajas.2002.851

29. Humer E, Zebeli Q. Grains in ruminant feeding and potentials to enhance their nutritive and health value by chemical processing. Anim Feed Sci Technol. 2017;226:133-51. https://doi. org/10.1016/j.anifeedsci.2017.02.005

30. Oh Y, Kim K, Choi CW, Kang S, Chung I, Nho W. Evaluation of feeding value of brown rice in Korean native beef steers (Hanwoo). J Anim Sci Technol. 2006;48:393-400. https://doi. org/10.5187/JAST.2006.48.3.393

31. McNiven MA, Hamilton RMG, Robinson PH, DeLeeuw JW. Effect of flame roasting on the nutritional quality of common cereal grains for non-ruminants and ruminants. Anim Feed Sci Technol. 1994;47:31-40. https://doi.org/10.1016/0377-8401(94)90157-0

32. Svihus B, Uhlen AK, Harstad OM. Effect of starch granule structure, associated components and processing on nutritive value of cereal starch: a review. Anim Feed Sci Technol. 2005;122:303-20. https://doi.org/10.1016/j.anifeedsci.2005.02.025

33. Eastridge ML, Firkins JL. Feed concentrates: cereal grains. In: Smithers GW, editor. Reference module in food science. Amsterdam: Elsevier; 2019.

34. Edwards JE, Huws SA, Kim EJ, Lee MR, Kingston-Smith AH, Scollan ND. Advances in microbial ecosystem concepts and their consequences for ruminant agriculture. Animal. 2008;2:653-60. https://doi.org/10.1017/S1751731108002164

35. Gordon GL, Phillips MW. The role of anaerobic gut fungi in ruminants. Nutr Res Rev. 1998;11:133-68. https://doi.org/10.1079/NRR19980009 